\title{
About the Current Status of Western-Based Prefixes Which are Used as Words in Turkish
}

\section{Anıl ÇELIK *}

* Bartın Üniversitesi E-mail: acelik@bartin.edu.tr

Copyright (C) 2015 Anıl ÇELIKK. This is an open access article distributed under the Eurasian Academy of Sciences License, which permits unrestricted use, distribution, and reproduction in any medium, provided the original work is properly cited.

\begin{abstract}
Turkish is an agglutinative language and it doesn't have prefixes. Just like the other languages, Turkish has established relationships with foreign languages from the time it arises and affected by them too. At first, due to Islam, Arabic and Persian languages influenced to Turkish, then affects of Western-based languages, such as French and English, were seen clearly. One of the foreign elements which get involved in Turkish from the other languages are prefixes. Turkish has taken some natural measures while including prefixes which are incompatible with its nature. Some western-based prefixes change their functions in Turkish language and they become words. This is an example of the mentioned measures. In this article, we are going to analyze the western-based prefixes which are used as words in Turkish and we will mention the structures and etymology of this prefixes in their own language. Finally, we are going to ensample their usage in Turkish with press products.
\end{abstract}

Keywords: Prefix, Agglutinative, Western languages, Compound word, Adjective, Noun, Etymology.

\section{Türkçede Kelime Olarak Kullanılan Batı Kaynaklı Ön Eklerin Bugünkü Durumu Üzerine}

\section{ÖZET}

Türkçe sondan eklemeli bir dildir ve ön ek bulundurmaz. Tıpkı diğer diller gibi Türkçe de ortaya çıktığı andan itibaren yabancı dillerle ilişkiler kurmuş ve bu dillerin etkisinde kalmıştır. Önce, İslamiyet ile birlikte Farsça ve Arapça dilleri Türkçe üzerinde etkilerini hissettirmiş, daha sonra Fransızca ve İngilizce başta olmak üzere batı kaynaklı dillerin etkisi açıkça görülmeye başlanmıştır. Bu etkileşim esnasında diğer dillerden Türkçeye giren yabancı unsurlardan biri de ön eklerdir. Türkçe, yapısıyla uyuşmayan ön ekleri bünyesine katarken birtakım doğal önlemler almıştır. Batı kaynaklı ön eklerden bazılarının Türkçede görev değiştirerek kelime olarak kullanılması bahsedilen önlemlere bir örnek teşkil eder. Bu makalede Türkçede kelime olarak kullanılan batı kaynaklı ön ekler incelenecek, bu ön eklerin kendi dillerindeki yapıları ve etimolojilerine değinilerek, bugün Türkçede nasıl yer aldıkları basın ürünleri aracılığıyla örneklenecektir.

Anahtar Kelimeler: Ön ek, Sondan eklemeli, Batı dilleri, Birleşik kelime, Sıfat, İsim, Etimoloji 


\section{GíRiş}

TDK Türkçe Sözlük'te ön ek; “Bazı yabancı dillerde kökün önüne gelerek kelimeye belirli bir anlam katan ek: anormal, biçare, nadan gibi." (TDK, 2011: 1853) şeklinde tanımlanır. Türkçe sondan eklemeli bir dil olduğundan yapısında ön ek bulundurmaz. Fakat "Türkçede karşımıza çıkan bazı kullanımlar zaman zaman araştırmacıları, Türkçede ön ek vardır yargısına götürmüş, ya da en azından olabileceğini düşündürtmüştür." (Şahin, 2006: 72) Bu kullanımların en dikkat çekeni "dilimize geçen yabancı ön ekli kelimelere Türkçe karşılıklar bulunması sırasında karşımıza çıkan ve ilk anda ön ekli kelime olduğu izlenimini uyandıran birleşik kelimelerdir." (Şahin, 2006: 67) Bununla birlikte pekiştirme ünsüzünün kullanılış1, dilimize kendi dillerindeki şekilleriyle giren ve ön ek bulunduran bazı kelimeler, kimi kelimelerin önünde görülen ön ses, yabancı bir ön ekle Türkçe bir kelimenin birleşmesi sonucu türetilmiş yapılar gibi dil unsurları da araştırmacıları Türkçede ön ek vardır yanlış yargısına götüren durumlardandır. Bu kullanımların bizi Türkçede ön ekin var olduğu sonucuna ulaştıramayacağı tespiti, Hatice Şahin'in “Türkçe'de Ön Ek” (Şahin, 2006: 65-77) isimli makalesinde sebepleri ve örnekleriyle açıklanmıştır.

Halil Ersoylu, 1993 yılında yazmış olduğu "Batı Kökenli Ön Eklerin Türk Dilinde Kelime Olarak Kullanılması" (Ersoylu, 1993: 326-333) isimli makalesinde batı kaynaklı bazı ön eklerin dilimizde ek göreviyle değil, birer kelime göreviyle yer almakta olduğunu tespit eder. Ersoylu, aynı makalede dilimize geçmiş bu tarz yapıların baş tacı edilmesini, yabancı eklerin kelime halinde, hızlı ve yaygın bir şekilde kullanılıyor olmasını eleştirir ve bunun dilimizdeki bir eksiklikten ya da dilimizde söz konusu yapılara karşılık bulunamayacak olmasından kaynaklanmadığını söyler. (Ersoylu, 1993: 332)

Biz ise Ersoylu'ya katılmakla beraber bu araştırmamızda meselenin başka bir boyutuna, bu tür kullanımların Türkçenin diğer dillerdeki ön ek yapılarını içine katarken, sondan eklemeli yapısı gereği aldığı bir önlem yöntemi olduğu noktasına odaklanacağız.

Kaldı ki, diller canlı varlıklardır ve dünya üzerinde kendinden başka bir dilden etkilenmemiş herhangi bir dil yoktur. Gelişen teknoloji ve kitle erişim araçlarının yaygınlaşması diller arası etkileşimi büyük oranda artırmıştır. Örneğin İngilizce Oxford Sözlüğü'ne yılda iki bin ila iki bin beş yüz yeni kelime girmektedir. Dilin doğal akışında kullanıcıları tarafından benimsenerek, o dile dahil edilen, o dile yerleşen yabancı kaynaklı kelimelerin varlığını reddetmek yerine, onları kayıt altına almak sözcük bilimi (leksikoloji) açısından uygun ve yararlı bir tutum olacaktır. Doğrusu, dil bu kelimeleri içine alırken yapısıyla örtüşmeyen kullanımları kendine has yöntemleriyle yontacak, işleyecek ve aşamalı bir şekilde yapısına uygun hale getirecektir. Hele ki Türkçe, köklü geçmişi ve yerleşik kurallarıyla bunu yapmaya son derece muktedirdir. Elbette her dilde olabileceği gibi Türkçede de bu kelimeler yanlış kullanım kalıntıları olarak kendilerine yer bulabilir. Dil kullanıcıları tarafından özümsenmiş böyle kelimeleri incelemeden dışlamak yerine "galat" olarak adlandıracağımız bu yapıların ayırdına gitmek ve doğru ile yanlışı belirlemek elzemdir. İşbu makalede Türkçede kelime olarak kullanılan batı kaynaklı ön eklerin dilimiz tarafından nasıl işlendiği, kullanılış ve uyum açısından bugün hangi aşamada olduğu gösterilmeye çalışılacak ve bu kullanımların kategorize edilmesine çabalanacaktır.

\section{Türkçede Batı Kaynaklı Ön Eklerin Kelime Olarak Kullanılması}

"Ekler, sözlük anlamı olmayan ama görev anlamları olan dil birimleridir. Öyleyse ekler, anlamsız dil birimleri olarak görülmemelidir." (Üstünova, 2010: 31) Bu tespit, batı dillerinde kullanılan ön ekler için de geçerlidir. Yani ön ekler de; görev anlamı olan ve sözlük anlamı olmayan bağımlı birimlerdir, çekime girmezler ancak yeni anlamda kelimeler türetebilirler. 
Söz konusu eklerden bazılarının Türkçedeki kullanımlarına bakıldığında bunların ön ek görevinde değil, sıfat yahut isim göreviyle bağımsız birimler halinde kullanılarak Türkçe kelimelerle çeşitli anlam ilişkileri kurdukları görülür. Yukarıdaki ön ek tanımının aksine, bu yapılar Türkçede, sözlük anlamları olan ve tek başlarına kullanılıp çekime giren bağımsız birimler, başka bir deyişle kelimeler olarak karşımıza çıkarlar. Bahsi geçen yapılar, uzun süredir dilimizde bulunmakta ve sayıca da giderek çoğalmaktadırlar. Böyle kelimelerin görünümlerine kanarak Türkçede ön eklerin görev almaya başladığı kanısına varmak kritik yanlışlara yol açar. Bu noktada, ön ek - kelime ayrımına gitmek ciddi önem taşımaktadır.

"Türkçede ön eklerin de var olduğu düşüncesini ortaya çıkaran kelimelerin öncelikle geldiği dildeki yapısını incelemek doğru bir tutum olacaktır." (Şahin, 2006: 76) Biz de bu tespiti göz önünde bulundurarak, ilkin sözü edilecek ön eklerin etimolojilerine ve kaynak dillerdeki kullanışlarına değinecek ve ardından bu eklerin dilimizdeki durumlarını değerlendireceğiz.

\section{A. Türkçede Kelime Olarak Kullanılan Batı Kaynaklı Ön Ekler}

Türk Dil Kurumu sözlüklerine bakıldığında, batı dillerinden dilimize geçerek kelime görevi kazanmış olan ön eklerden bazılarına bu sözlüklerde yer verildiği, bazılarının ise belirtilen sözlüklerin içeriklerinde yer almadığ 1 görülür.

Türkiye'de sözlükçülük halen gelişme aşamasında olduğundan bir kelimenin dilimize yerleşip yerleşmediğini anlamanın en gerçekçi yolu halkın dilini incelemektir. Günümüzde, kitle iletişim araçlarının halkın diline etkisi yadsınamayacak derecededir, medya toplumun her kesimine hitap ettiği ve malzemelerini icra edicileri sanatsal kaygılar gütmediği için yaşayan Türkçenin temsil edildiği bir alandır. Biz de bundan dolayı araştırmamızda yer verdiğimiz kelimeleri mümkün olduğunca basın ürünleri aracılığılla örneklemeyi tercih ettik.

Aşağıda, dilimizde kelime göreviyle yer almış bağımsız ön ekler dışında, bu ekleri içerip yabancı dillerdeki birleşik şekilleriyle dilimize geçen ve dilimizde kök sayılan kelimeler ayrı başlıklar altında gösterilmiştir. Bu yapıların listelenmesi, Türkçede ön ek vardır yanlış yargısını ortadan kaldırmak açısından yararlıdır. Galat kullanımlar olan ve dilimizde batı kaynaklı ön ek yapısıyla bitişik yazılan Türkçe menşeli kelimeler de örneklerde kendilerine yer bulmuştur.

Yaşayan Türkçede kelime olarak kullanılan batı kaynaklı ön eklerden başlıcaları şunlardır; ${ }^{1}$

auto-: Kökeni Eski Yunanca "kendi” anlamındaki "autós" biçimine dayanmakta olup eklendiği kelimeye "kendi kendine" anlamı katan bir ön ektir. Fransızcada bulunan "auto" kelimesi ise "araba, otomobil" anlamına gelen ve bu ön ekle kurulmuş "automobile" kelimesinden kısaltılarak türetilmiştir. Dilimizde de söz konusu Fransızca "auto" kelimesi aracıllı̆̆ıyla, "oto" biçiminde ve isim görevinde ayrı bir kelime olarak yer almıştır.

oto: Otomobil sözcüğünün kısaltılmışı, araba, taksi.

"Sürücü ekip otosuna bindirilerek gözaltına alındl. "

(http://www.gazetevatan.com/tem-otoyolunda-bir-garip-olay--785082-yasam, 08.06.2015)

\footnotetext{
1 Kelimelerin tanımlamaları ve etimolojileri gösterilirken "TDK Büyük Türkçe Sözlük” (http://www.tdk.gov.tr/index.php?option=com bts\&view=bts $\quad 008.06 .2015$ ), “Dictionary.com” (http:// http://dictionary.reference.com , 08.06.2015), "Sözlerin Soyağacı" (Nişanyan, 2012) gibi kaynaklardan yararlanılmıştır.
} 
Dilimizde, kaynak dillerdeki şekilleriyle görülen "auto-“ ön ekli kelimelere örnekler: otokontrol, otomobil, otomasyon, otomatik, ototrof...

cardio-: Kökeni Eski Yunanca "kalp" anlamındaki "kardía" kelimesine dayanmakta olup eklendiği kelimeye "kalbe ait, kalple ilgili" anlamları katan bir ön ektir. İngilizcede bu ekle başlayan kelimelerden kısaltılarak türetilmiş "kalbi daha güçlü ve daha sağl1klı çalıştırmak için yapılan herhangi bir egzersiz türü anlamında bir "cardio" ismi de kullanılmaktadır. Dilimizde de söz konusu İngilizce "cardio" ismi aracılı̆̆ıyla, "kardiyo" biçiminde ve isim görevinde ayrı bir kelime olarak yer almıştır.

kardiyo: Kalple ilgili (egzersiz), kardiyovasküler (egzersiz).

"Koşu, yüzme ve bisiklete binmek gibi kardiyo egzersizlerinin, 20 ylllı dönemde düşünme yetilerini ve hafızayı güçlendirdiği ortaya çıktı."

(http://www.cumhuriyet.com.tr/haber/saglik/57323/Duzenli_egzersiz_beyni_guclendiriyor_. html , 08.06.2015)

Dilimizde, kaynak dillerdeki şekillleriyle görülen "cardi(o)-“" ön ekli kelimelere örnekler: kardiyografi, kardiyogram, kardiyosel, kardiyoskleroz, kardiyoskop...

contra-: Kökeni Latince "karşı, zıt" anlamlarına gelen "contra-" edat ve ön ekine dayanmakta olup İtalyanca eklendiği kelimeye "karşı, zıt" anlamları katan bir ön ektir. Fransızcada "contre", İngilizcede "counter" biçimleriyle kullanılır. Dilimize sıfat göreviyle "kontra" biçiminde ayrı bir kelime olarak yerleşmiştir.

kontra: Karşı1t, karşı, aksi.

“Trabzonspor'dan kontra hukuk hamlesi...

(http://www.hurriyet.com.tr/spor/futbol/26469145.asp, 08.06.2015)

Dilimizde, kaynak dillerdeki şekilleriyle görülen "contra-“ ön ekli kelimelere örnekler: kontrasepsiyon, kontraseptif, kontrast, kontratak...

crypt(o)-: Kökeni Eski Yunanca "gizli" anlamındaki "kruptos" biçimine dayanmakta olup eklendiği kelimelere "saklı, gizli" anlamları katan bir ön ektir. Fransızcada bulunan "crypto" kelimesi ise "saklı yazı" anlamına gelen ve bu ön ekle kurulmuş "cryptogramme" kelimesinden kısaltılarak türetilmiştir. Dilimizde de söz konusu Fransızca "crypto" kelimesi aracılığıyla, "kripto" biçiminde ve isim görevinde ayrı bir kelime olarak yer almıştır. Dilimizde "siyasi inancını gizleyen kimse" anlamında yerleşen "kripto" sözcüğünün bir diğer kullanımının ise Fransızca "crypto-chrétien, crypto-juif", "gizli hıristiyan, gizli yahudi” vb. yapılardan kısaltılarak ortaya çıkarıldığı tahmini dile getirilebilir.

kripto: 1. Siyasi inancını gizleyen kimse. 2. Saklı yazı.

Siyasi inancını gizleyen kimse;

\section{"Kripto Hristiyanlar ve gizli Ermeniler olarak varlıklarını nasıl korumuştular?”}

(http://www.turkiyegazetesi.com.tr/yildiray-ogur/577933.aspx , 08.06.2015)

Saklı Yazı; 
"Kripto soruşturmasında 28 sanık hakkında ağırlaştırılmış müebbet hapis cezast isteniyor."

(http://www.cumhuriyet.com.tr/haber/turkiye/232779/Kripto_sorusturmasinda_agirlastirilmis _muebbet_istemi.html, 08.06.2015)

Dilimizde, kaynak dillerdeki şekilleriyle görülen "crypt(o)-“ ön ekli kelimelere örnekler: kriptofit, kriptoloji, kriptosiyanin, kriptozoit...

dactylo-: Kökeni Eski Yunanca "parmak" anlamındaki “daktulos" kelimesine dayanmakta olup eklendiği kelimeye "parmakla ilgili" anlamı katan bir ön ektir. Fransızcada bulunan "dactylo" kelimesi ise "parmakla yazı yazma aygıtı" anlamına gelen ve bu ön ekle kurulmuş "dactylographe" kelimesinden kısaltılarak türetilmiştir. Dilimizde de söz konusu Fransızca "dactylo" kelimesi aracılığıyla, "daktilo" biçiminde ve isim görevinde ayrı bir kelime olarak yer almıştır.

daktilo: 1. Yazı makinesi 2. daktilograf.

Yazı makinesi;

“Bilgisayar teknolojisinde yaşanan tüm gelişmelere rağmen daktilo meraklıları alışkanlıklarından vazgeçmiyor. "

(http://arsiv.sabah.com.tr/2007/11/16/haber,64C75BBB8B9D4143BB31E874FFCBCB98.htm $1,08.06 .2015)$

Daktilograf;

"Bir daktilonun ille hanende olması şart değildir."

(http://www.tdk.gov.tr/index.php?option=com_gts\&arama=gts\&guid=TDK.GTS.557587933f $1270.52136440,08.06 .2015)$

Dilimizde, kaynak dillerdeki şekilleriyle görülen "dactylo-" ön ekli kelimelere örnekler: daktilograf, daktilojiroz, daktilomegali, daktiloskopi, daktilotekni...

dynamo-: Kökeni Eski Yunanca "güç" anlamına gelen "dunamis" kelimesine dayanmakta olup eklendiği kelimeye "güç, enerji" anlamlarını katan bir ön ektir. Fransızcada bulunan "dynamo" kelimesi ise Almanca "dynamoelektrische maschine", "gücü elektrik akımına çeviren motor" kelimesinin kısaltılmasıyla türetilmiştir. Dilimizde de söz konusu Fransızca "dynamo" kelimesi aracılığıyla, "dinamo" biçiminde ve isim görevinde ayrı bir kelime olarak yer almıştır.

dinamo: 1. Üreteç 2. (mec.) sürükleyici.

Üreteç;

"Şarj dinamosu ile aküyü geri besliyorum. Bunun ekstra bir masrafi yok."

(http://www.milliyet.com.tr/hayvan-daminda-elektrik-uretti-ozel-balikesir-yerelhaber-602357 , 08.06.2015) 
Sürükleyici;

“İtalyan basını Lazio'nun, Beşiktaş orta sahasının dinamosu Veli Kavlak ile ilgilendiğini yazdl."

(http://www.hurriyet.com.tr/spor/futbol/27761364.asp , 08.06.2015)

Dilimizde, kaynak dillerdeki şekilleriyle görülen "dynamo-“ ön ekli kelimelere örnekler: dinamometre...

ex-: Bedri Aydoğan, "Ex Aşkım, Eks Aşkın, Ex Aşkl” (Aydoğan, 2006: 507-516) isimli makalesinde bu ön ek ve sözcük hakkında "Sözcük, Latince "exitus"tan gelmektedir. Ingilizcedeki "exit" de aynı köktendir. Çıkmak, gitmek, ayrılmak, gidiş, çıkış anlamlarını taşımaktadır. "Exit" ölüm, ölmek ve vefat etmek anlamlarına da gelmektedir. Ancak ölmek karşıllğında "exit" bizde kullanilmamaktadır. Bunun yerine tıp terimi olarak "ex", "ex olmak" kullanımlarl vardır. Sözcük bu anlamıyla ve tıp terimi olarak doktorlar arasında geçerliyse de gündelik dilde yer almıyordu. Ancak zaman içinde yine gazeteciler, yazarlar ölüm karşılığında "ex"i kullandılar ve yaygınlaştırdılar. Prof. Dr. Hamza Zülfikar, Bingöl depreminde bölgeden haber aktaran muhabirin "Bir çocuk eks olarak çıkarıldı" demesi ve haberin devamında peş peşe "eks"i kullanması üzerine bir yazı yazdl. Dilimizde eks karşıllğında yetmişe yakın Türkçe sözcük ve söz grubunun olduğunu belirledi ve örnekler verdi. "Eks"e gereksinmemiz olmadiğını gösterdiği gibi Türkçenin söz varliğının zenginliği ile anlatım yollarındaki yetkinliğini de ortaya koydu. "Ex"in gitme, çıkma, ölme anlamları olduğunu söylemiş ve bizde daha çok ölüm anlamında kullanıldığına değinmiştik. Bu, tıp terimi olarak sınırlı bir kullanımdı. Gündelik dili de çok ilgilendirmiyordu. "Ex" sözcüğü bir ön ek olarak da kullanılıyor, "-den dişarı, -den fazla, -sız ve olmadan" anlamları taşıyordu. Yine eski, sabık (geçen, geçmiş) ve eski eş anlamlarına da geliyordu." (Aydoğan, 2006: 508-509) demektedir. Biz de konumuzu gereği yalnızca sözü geçen ön ek aracılığıyla dilimize geçen "eski, önceki, eski eş" anlamlarına gelen "ex" biçimini inceleyeceğiz.

ex: Eski, önceki.

"Yıllar önce aşk yaşadiğı Ece'nin ex aşkı Yavuz, Emir'in peşinde bir gölge gibi..."

(http://www.gazetevatan.com/feriha-hamile-mi--457096-medya , 08.06.2015)

Dilimizde, kaynak dillerdeki şekilleriyle görülen "ex-“ ön ekli kelimelere örnekler: eksartikülasyon, eksfolyatif, ekshalant, eksplant, ekstübasyon...

extra-: Kökeni Latince "dışarı, dışarıda, dışında" anlamlarındaki "extra" biçimine dayanmakta olup eklendiği kelimeye "dışında, ötesinde" anlamları katan bir ön ektir. Fransızca/ İngilizcede bulunan "extra" kelimesi ise "sıradışı, olağandışı" anlamına gelen ve bu ön ekle kurulmuş "extraordinaire" veya "extraordinary" kelimelerinden kısaltılarak türetilmiştir. Dilimizde de söz konusu İngilizce/Fransızca "extra" kelimesi aracılığıyla, "ekstra" biçiminde ve sıfat görevinde ayrı bir kelime olarak yer almıştır.

ekstra: 1. En iyi, üstün nitelikli 2. Fazladan, alışılan ve gerekenden başka, ek olarak.

En iyi, üstün nitelikli; 


\section{“Ekstra Un.” (TDK, 2011: 772)}

Fazladan, alışılan ve gerekenden başka, ek olarak;

"Futbolcular birbirleri ile rekabet içinde olduğu için herhangi bir takım arkadaşının yağ oranı kendisinden düşükse bu o oyuncu için ekstra bir motivasyon sağllyor."

(http://www.hurriyet.com.tr/spor/futbol/26835644.asp , 08.06.2015)

Dilimizde, kaynak dillerdeki şekilleriyle görülen "extra-" ön ekli kelimelere örnekler: ekstrafor, ekstrahepatik, ekstraksiyon, ekstramural, ekstravasküler...

hyper-: Kökeni Eski Yunanca "üstte veya üzeri olma, yukarı doğru hareket etme" bildiren "huper" edat ve fiil ön ekine dayanmakta olup eklendiği kelimelere "üstün, aşırı" anlamlarını katan bir ön ektir. Dilimizde de Fransızca/Ingilizce "hyper-" ön eki aracılığıyla "hiper" biçiminde ve sıfat görevinde ayrı bir kelime olarak yer almıştır.

hiper: Üstün, çok büyük.

“Gazeteci Dominique Vidal, ABD'nin her şeye muktedir bir hiper güç olmadığını dile getirdiği konuşmasında şunları söyledi..."

(http://www.cumhuriyet.com.tr/haber/diger/238028/Turk_ogrenciler_Paris_te_toplandi.html , 08.06.2015)

Dilimizde, kaynak dillerdeki şekilleriyle görülen "hyper-" ön ekli kelimelere örnekler: hiperaktif, hiperapoliz, hiperazotemi, hiperbolik, hiperglisemi...

kilo-: Kökeni Eski Yunanca "bin" anlamına gelen "chîlioi" biçimine dayanmakta olup eklendiği kelimelere "bin" anlamı katan bir ön ektir. Fransızcada bulunan "kilo" kelimesi ise "bin gramlık tartı birimi" anlamına gelen ve bu ön ekle kurulmuş "kilogramme" kelimesinden kısaltılarak türetilmiştir. Dilimizde de söz konusu Fransızca "kilo" kelimesi aracılığıyla, "kilo" biçiminde ve isim görevinde ayrı bir kelime olarak yer almıştır.

kilo: 1. Kilogram 2. bir varlığın ağırlı̆̆1.

Kilogram;

“Günde 2 kez, 15 'er dakikalı yürüyüss size ayda yarım kilo kaybettirir."

(http://www.gazetevatan.com/10-kucuk-degisiklikle-5-kilo-verin--747615-pazar-vatan 08.06.2015)

Bir varlığın ağırlığı;

"Kilosu nedeniyle yatağa bağlanan ve nefes almakta bile güçlük çeken İtah, artık arkadaşlartyla oyun oynayabiliyor. “

(http://www.hurriyet.com.tr/ankara/28763748.asp , 08.06.2015)

Dilimizde, kaynak dillerdeki şekilleriyle görülen "kilo-“ ön ekli kelimelere örnekler: kiloamper, kilogram, kilokalori, kiloton, kilovat... 
macro-: Kökeni Eski Yunanca "büyük" anlamındaki "makrós" biçimine dayanmakta olup eklendiği kelimelere "büyük, uzun, aşırı" anlamlarını katan bir ön ektir. Fransızcada bulunan ve "geniş, büyük" anlamlarına gelen "macro" sıfat ve isminin ise "macro-" ön ekinin müstakil bir kullanımı olduğu veya bu ön ekle kurulan kelimelerden kısaltılarak türetildiği tahmini dile getirilebilir. Dilimizde de söz konusu Fransızca "macro" kelimesi aracılığıyla, "makro" biçiminde ve sıfat görevinde ayrı bir kelime olarak yer almıştır.

makro: Büyük, geniş, mikro karşıtı.

“Ekonomi genelinde makro düzeyde veriler, gelişmeler, işletmelerin, mikro düzeydeki verilerin toplamı sonucudur.

(http://www.cumhuriyet.com.tr/koseyazisi/241988/isletme_Yonetimlerine_Odaklanmak....ht $\mathrm{ml}, 08.06 .2015)$

Dilimizde, kaynak dillerdeki şekilleriyle görülen "macro-" ön ekli kelimelere örnekler: makroekonomi, makrosefal, makrositemi, makrospor, makrostopi...

Dilimizde, önündeki "makro" yapısıyla bitişik yazılan Türkçe menşeli kelimelere örnekler: makrobesinler, makroişlemci...

Not: Yunanca kökenli “makro-“ ön eki ve Arapça kökenli "iktisat” kelimelerinden mürekkep "makroiktisat" kelimesi de doğrudan bir alıntı olmadığı halde Türkçede birleşik yazılmaktadır.

maxi-: Kökeni Latince "en büyük" anlamındaki "maximus" kelimesine dayanmakta olup eklendiği kelimelere "en büyük" anlamı katan bir ön ektir. "mini-“" ön ekine analoji (örnekseme) yoluyla "maximum" kelimesinden kısaltılarak türetilmiştir. Dilimizde de Fransızca "maxi-" ön eki aracılığıyla, "maksi” biçiminde sıfat ve isim görevinde ayrı bir kelime olarak yer almıştır.

maksi: 1. Uzun 2. Uzun etek.

Uzun;

"Batik boyamalar ve uçuşan kumaşlar, maksi elbiseler oldukça popüler."

(http://www.haberturk.com/yasam/haber/1023969-2015-e-sicacik-merhaba , 08.06.2015)

Uzun etek;

"Mini mi maksi mi? Moda tasarımcıları ne düşünüyor?”

(http://arsiv.sabah.com.tr/2007/05/05/ct/haber,5768DBAB4271497A8E08A4E3F0644071.ht $\mathrm{ml}, 08.06 .2015)$

mega-: Kökeni Eski Yunanca "çok büyük, güçlü” anlamlarına gelen "megas" kelimesine dayanmakta olup eklendiği kelimelere "büyük, bir ölçü biriminin milyon katı" anlamlarını katan bir ön ektir. Dilimizde de Fransızca/İngilizce "mega-" ön eki aracılığıyla "mega" biçiminde ve sıfat görevinde ayrı bir kelime olarak yer almıştır.

mega: Büyük, çok büyük.

"Yepyeni bir İstanbul'a mega projeyle hep birlikte yürüyoruz." 
(http://www.sabah.com.tr/gundem/2015/02/27/mega-proje-aciklandi , 08.06.2015)

Dilimizde, kaynak dillerdeki şekilleriyle görülen "mega-" ön ekli kelimelere örnekler: megabayt, megastar, megafon, megametre, megaton...

Not: Yunanca kökenli "mega-“ ön eki ve Soğdça kökenli "kent” kelimelerinden mürekkep "megakent" kelimesi de doğrudan bir alıntı olmadığı halde Türkçede birleşik yazılmaktadır.

metro-: Kökeni Eski Yunanca "anne" anlamına gelen "mētér" sözcüğüne dayanmakta olup önüne geldiği kelimeye "anne veya rahim ile ilgili" anlamı katan bir ön ektir. Fransızcada bulunan "métro" kelimesi ise "büyükşehirlerde semtler arasında işleyen, ulaşımı yerin altında sağlayan tren, yer altı treni" anlamına gelir ve bu ön ekle kurulmuş "métropolitain" kelimesinden kısaltılarak türetilmiştir. Dilimizde de söz konusu Fransızca "métro" kelimesi aracılığıyla, "metro" biçiminde ve isim görevinde ayrı bir kelime olarak yer almiştır.

metro: Büyükşehirlerde semtler arasında işleyen, ulaşımı yerin altında sağlayan tren, yer altı treni.

"Adana'da $\underline{\text { metro }}$ durağına otomobille uçan 2 polis memurunun ölümüyle ilgili $\underline{\text { metro }}$ inşaatının kontrol firmasında çalışan 8 kişi hakkında dava açıldı."

(http://www.hurriyet.com.tr/gundem/27765827.asp, 08.06.2015)

Dilimizde, kaynak dillerdeki şekilleriyle görülen "metro-" ön ekli kelimelere örnekler: metropol, metroparaliz, metropati, metrosel...

micro-: Kökeni Eski Yunanca "küçük" anlamındaki "mīkrós" biçimine dayanmakta olup eklendiği kelimelere "küçük" anlamı katan bir ön ektir. Fransızcada bulunan ve "son derece küçük" anlamına gelen "micro" sıfat ve isminin ise "micro-" ön ekinin müstakil bir kullanımı olduğu veya bu ön ekle kurulan kelimelerden kısaltılarak türetildiği tahmini dile getirilebilir. Dilimizde de söz konusu Fransızca "micro" kelimesi aracılığıyla, "mikro" biçiminde ve sıfat görevinde ayrı bir kelime olarak yer almıştır.

mikro: Küçük, dar, makro karşıtı.

"Uzmanlar silikona göre fiyat avantajı olduğunu söylese de bu plastik mikro işlemci yolun henüz çok başında."

(http://www.aksam.com.tr/teknoloji/islemci-ve-ramde-yeni-donem-basliyor--30009h/haber$30009,08.06 .2015)$

Dilimizde, kaynak dillerdeki şekilleriyle görülen "micro-"“ ön ekli kelimelere örnekler: mikroaerofil, mikrobiyoloji, mikrodifüzyon, microekonomi, mikroelektrot...

Dilimizde, önündeki “mikro" yapısıyla bitişik yazılan Türkçe menşeli kelimelere örnekler: mikrobilgisayar, mikrodalga, mikrokomut, mikrotüpçük... 
midi-: Kökeni Latince "orta" anlamına gelen "medius" kelimesine dayanmakta olup eklendiği kelimeye "orta boyda" anlamı katan bir ön ektir. "maxi-" ve "mini-" ön eklerinden analoji (örnekseme) yoluyla, "mid-“" ön ekinden yola çıkılarak türetilmiştir. Dilimizde de Fransızca "midi-" ön eki aracılığıyla, "midi” biçiminde sıfat görevinde ayrı bir kelime olarak yer almıştır. (İngilizce "Musical Instrument Digital Interface" yapısındaki kelimelerin baş harflerinden türetilmiş bir akronim olan ve dilimizde çok yaygın olmasa da kullanılan "Ses sinyali için çalgı aletleri ile bilgisayar gibi çeşitli elektronik cihazlar arasında ortak bir dil oluşturmak amacıyla geliştirilmiş dijital arayüz” anlamındaki "midi” sözcüğünün bu ön ekle herhangi bir ilgisinin olmadığını belirtmek gerekir.)

midi: Orta.

"Birçok tasarımcının özellikle midi boyda yaptığ kloş etekler yaz gardıroplarının vazgeçilmez kurtarıcılarından olacak.”

(http://www.sabah.com.tr/cumartesi/2011/04/30/ilkbahar--yaz-trendleri , 08.06.2015)

Dilimizde, kaynak dillerdeki şekilleriyle görülen "midi-“ ön ekli kelimelere örnekler: midibüs...

mini-: Kökeni Latince “daha küçük, daha az" anlamlarındaki "minus/minor” biçimlerine dayanmakta olup eklendiği kelimelere "küçük" anlamı katan bir ön ektir. Fransızcada "miniature, minimum" sözcüklerinden kısaltılarak türetilmiştir. Dilimizde de söz konusu Fransızca "mini" kelimesi aracılığıyla, "mini” biçiminde sıfat görevinde ayrı bir kelime olarak yer almıştır. (Türkçede aynı anlamı ifade eden "mini mini”" yapısının bu kelimeyle etimolojik bir bağının olmadığını da belirtmek gerekir.)

mini: 1 . Çok küçük veya kısa 2. Kısa etek.

Çok küçük veya kısa;

"Meksika bugünlerde ilginç bir mini etek skandalıyla çalkalanıyor."

(http://www.sabah.com.tr/dunya/2013/02/17/mini-etekle-meclise-gelinir-mi , 08.06.2015)

Klsa etek;

"Mini mi maksi mi? Moda tasarımcıları ne diyor?"

(http://arsiv.sabah.com.tr/2007/05/05/ct/haber,5768DBAB4271497A8E08A4E3F0644071.ht $\mathrm{ml}, 08.06 .2015)$

Dilimizde, kaynak dillerdeki şekilleriyle görülen "mini-“ ön ekli kelimelere örnekler: minibüs, minimetre, minizom...

Dilimizde, önündeki “mini” yapısıyla bitişik yazılan Türkçe menşeli kelimelere örnekler: minibilgisayar, minigöreç, minigöz, miniölçer, minitartaç...

photo-: Kökeni Eski Yunanca "1şık" anlamındaki "phôs" kelimesine dayanmakta olup önüne geldiği kelimeye "1şık" anlamı katan bir ön ektir. Fransızcada bulunan "photo" kelimesi ise "fotoğraf" anlamina gelir ve bu ön ekle kurulmuş "photographe" kelimesinden kısaltılarak türetilmiştir. Dilimizde de söz konusu Fransızca "photo" kelimesi ve "photo-" ön eki aracılığıla, "foto" biçiminde ve isim görevinde ayrı bir kelime olarak yer almıştır. 
foto: 1 . Işık 2. Fotoğraf.

Iş1k;

“Carlson, fotoiletken özellikli materyaller üzerinde elektrostatik denemeler yaptı ve elektrik ışı̆̆ına maruz kalan nesnelerin görüntülerini yansıttıklarını keşfetti.",

(http://www.hurriyet.com.tr/index/ArsivNews.aspx?id=3942982, 08.06.2015)

Fotoğraf;

“Milliyet'in başarll foto muhabiri Bünyamin Aygün, 21 gün önce haber amacryla gittiği Suriye'de muhalif gruplar tarafindan kaçırıldı."

(http://www.radikal.com.tr/turkiye/milliyet_muhabiri_suriyede_kacirildi-1166697 08.06.2015)

Dilimizde, kaynak dillerdeki şekilleriyle görülen "foto-" ön ekli kelimelere örnekler: fotoğraf, fotojenik, fotomontaj, fotosel, fotosentez...

Dilimizde, önündeki “foto" yapısıyla bitişik yazılan Türkçe menşeli kelimelere örnekler: fotoakım, fotoayrışma, fotoçoğaltıcı, fotogerçekçilik, fotobozunma...

retro-: Kökeni Latince "geri, geriye, geride" anlamlarına gelen "retrō" zarfina dayanmakta olup önüne geldiği kelimeye "geriye, geride" anlamı katan bir ön ektir. İngilizcede bulunan "retro" kelimesi ise "modası geçmiş iken yeniden moda olan" anlamına gelir ve bu ön ekle kurulmuş "retrospective" kelimesinden kısaltılarak türetilmiştir. Dilimizde de söz konusu İngilizce "retro" kelimesi aracılığıyla, "retro" biçiminde isim ve sıfat görevinde ayrı bir kelime olarak yer almıştır.

retro: Modası geçmiş iken yeniden moda olan.

"Bir giyim markasının yeni koleksiyonu için objektif karşısına geçen oyuncu Wilma Elles, $\underline{\text { retro }}$ kadını oldu."

(http://www.milliyet.com.tr/-ret-ro---wil-ma-magazin-1959165, 08.06.2015)

super-: Kökeni Latince "üst, üzeri, yukarı" anlamındaki "super" edat ve fiil ön ekine dayanmakta olup eklendiği kelimelere "yukarıda, ötesinde" anlamlarını katan bir ön ektir. Fransızcada bulunan ve "üstün" anlamına gelen "super" kelimesinin ise "super-" ön ekinin müstakil bir kullanımı olduğu veya bu ön ekle kurulan çok çeşitli sözcüklerden kısaltılarak türetildiği tahmini dile getirilebilir. Dilimizde de söz konusu Fransızca "super" kelimesi aracılığıyla, "süper" biçiminde ve sıfat görevinde ayrı bir kelime olarak yer almıştır.

süper: Nitelik, nicelik ve derece bakımından üstün olan.

"Savunma analistleri, yapllacak kesintilerin gelecekte ABD’yi dünyanın süper gücü konumundan düşüreceğini öne sürdü."

(http://www.radikal.com.tr/dunya/abd_artik_super_guc_olmayacak-1058816,08.06.2015) 
Dilimizde, kaynak dillerdeki şekilleriyle görülen "super-“ ön ekli kelimelere örnekler: superiyor, superfisyal...

taxi-: Kökeni Latince "değer biçmek hesaplamak" anlamlarına gelen "taxare" biçimine dayanmakta olup önüne geldiği kelimeye "ücretle ilgili, tarife ile ilgili" anlamı katan bir ön ektir. Fransızcada bulunan "taxi" kelimesi ise "Belirli bir ücret karşılığı yolcu taşıyan, taksimetresi olan otomobil" anlamına gelir ve bu ön ekle kurulmuş bir kelimeyi içeren "voiture à taximètre", "tarife ölçme cihazı ile donatılmış at arabası" yapısından kısaltılarak türetilmiştir. Dilimizde de söz konusu Fransızca "taxi” kelimesi aracıllı̆̆ıla, "taksi" biçiminde ve isim görevinde ayrı bir kelime olarak yer almıştır.

taksi: Belirli bir ücret karşıllı̆̆ yolcu taşıyan, taksimetresi olan otomobil.

“İstanbul'da ticari taksiler için yeni bir dönem başlyyor."

(http://www.cumhuriyet.com.tr/haber/turkiye/140057/istanbul_da_taksiler_icin_yeni_donem_ _Taksiciler_tepkili.html, 08.06.2015)

Dilimizde, kaynak dillerdeki şekilleriyle görülen "taxi-“" ön ekli kelimelere örnekler: taksimetre...

tele-: Kökeni Eski Y unanca "uzak" anlamına gelen "télos” biçimine dayanmakta olup eklendiği kelimelere "uzak, uzak mesafelere veri iletimi" anlamları katan bir ön ektir. Dilimize de Fransızca/İngilizce "tele-" ön eki aracılığıyla "tele” biçiminde geçmiştir.

tele: 1. Uzak mesafelere veri iletimi sağlayan. 2. Televizyon.

Uzak mesafelere veri iletişimi sağlayan;

"Limanda iş yapan firmaların rüşvet olarak kamu görevlilerine telekız servisi yaptı̆̆ da görüntülerle polis takibine takıldı.”

(http://www.gazetevatan.com/is-adamindan-telekiz-servisi--599450-gundem, 08.06.2015)

Televizyon;

“Yıllar sonra Tele Pazar'a Dönüş"

(http://www.sabah.com.tr/yazarlar/uluc/2008/04/05/yillar_sonra_tele-pazar_a_donus, 08.06.2015)

Dilimizde, kaynak dillerdeki şekilleriyle görülen "tele-" ön ekli kelimelere örnekler: teleferik, telefon, telemetre, telepati, televizyon...

Dilimizde, önündeki "makro" yapısıyla bitişik yazılan Türkçe menşeli kelimelere örnekler: telekız, telekulak...

trans-: Kökeni Latince "aracılığıyla, ötesinde, karşısında" anlamındaki "trāns" edat ve zarfına dayanmakta olup eklendiği kelimelere "öbür tarafta, karşı tarafında, ötesinde” anlamlarını katan bir ön ektir. İngilizcede bulunan "trans" kelimesi ise "cinsiyet değiştiren (kimse)" anlamına gelen ve bu ön ekle kurulmuş "transsexual" kelimesinden kısaltılarak türetilmiştir. Dilimizde de söz konusu İngilizce "trans" kelimesi aracılığıla, "trans" biçiminde ve isim görevinde ayrı bir kelime olarak yer almıştır. (Türkiye Türkçesinde trans kelimesiyle aynı anlamda 
transseksüel kelimesinin de kullanılmakta olduğunu belirtmek gerekir.) (Fransızca "transe" kelimesi aracılığıyla dilimize girmiş ve "kendinden geçme" anlamında gelen "trans" kelimesinin bu kelimeyle bağlantılı olmadığını belirtmek gerekir.)

trans: Hormon tedavisi görüp ameliyat olarak cinsiyet değiştiren.

I. “Avcılar'da trans bir kadını öldürdüğ̈̈ için müebbet hapsi istenen sanık Soybozkurt, indirimle 15 yll hapis cezası aldl."

II. (http://www.milliyet.com.tr/trans-oldurmek-indirime-gerekce--gundem-1892227, 08.06.2015)

Dilimizde, kaynak dillerdeki şekilleriyle görülen "trans-" ön ekli kelimelere örnekler: transaminasyon, transatlantik, transfektan, transfüzyon, transkripsiyon...

ultra-: Kökeni Latince “öte,aşırı” anlamlarındaki "ultrā” edat ve zarfına dayanmakta olup eklendiği kelimelere "ötesinde" anlamı katan bir ön ektir. Fransızcada/İngilizcede bulunan ve "aşırı, sıradanın ötesinde olan" anlamına gelen "ultra" kelimesinin ise "ultra-" ön ekinin müstakil bir kullanımı olduğu veya bu ön ekle kurulan çok çeşitli sözcüklerden kısaltılarak türetildiği tahmini dile getirilebilir. Dilimizde de söz konusu Fransızca/İngilizce "ultra" kelimesi aracılığıyla, "ultra" biçiminde ve sıfat görevinde ayrı bir kelime olarak yer almıştır.

ultra: Aşırı.

III. "Dünya genelinde ultra zenginlerin sayısı artt1."

IV. (http://www.milliyet.com.tr/ultra-zenginlerin-sayisiartti/ekonomi/detay/1972312/default.htm , 08.06.2015)

Dilimizde, kaynak dillerdeki şekilleriyle görülen "ultra-“ ön ekli kelimelere örnekler: ultrafiltrasyon, ultrasantrifüj, ultrason, ultraviyole...

Dilimizde, önündeki "ultra" yapısıyla bitişik yazılan Türkçe menşeli kelimelere örnekler: ultraküresel, ultrases, ultrasüzgeç....

Dilimizde, kaynak dillerdeki şekilleriyle görülen "retro-" ön ekli kelimelere örnekler: retroenfeksiyon, retrofarengiyal, retrognati, retrospektif...

video-: Kökeni Latince "görüyorum" anlamına gelen "video" yapısına dayanan bir ön ektir. İngilizcede bulunan "video" kelimesi ise bu ön ekle kurulmuş "video cassette recorder" yapısından kısaltılarak türetilmiştir. Dilimizde de söz konusu İngilizce "video" kelimesi aracılığıyla, "video" biçiminde isim görevinde ayrı bir kelime olarak yer almıştır.

video: 1 . Manyetik bantlar üzerinde yer alan veya sayısal olarak derlenmiş hareketli resimler dizisi 2. Videoteyp.

Manyetik bantlar üzerinde yer alan veya sayısal olarak derlenmiş hareketli resimler dizisi;

"Video kaydının ise bir onbaşı tarafindan çekildiği belirtildi."

(http://www.milliyet.com.tr/2006/02/13/dunya/axdun02.html , 08.06.2015) 
Videoteyp;

"Kaseti taktı videoya, izlemeye başladı Kemal..."

(http://www.cnnturk.com/2013/guncel/05/04/yasar.kemalin.ince.memedi.korsan.filmcilerin.el inde.nasil.ince.mehmet.oldu/706605.0, 08.06.2015)

Dilimizde, kaynak dillerdeki şekilleriyle görülen "video-“ ön ekli kelimelere örnekler: videobant, videokaset, videoteyp...

\section{SONUÇ}

Türkçede kelime olarak kullanılan batı kaynaklı ön eklerin bugünkü durumuna bakıldığında bu kelimelerle ilgili çeşitli sınıflandırmalar ve tespitler yapmanın mümkün olduğu görülecektir. Buna göre;

- Makalede maddeler halinde listelenmiş ve basın ürünleri aracılığıyla örneklenmiş Türkçede kelime olarak kullanılan batı kaynaklı ön eklerden;

a. TDK Büyük Türkçe Sözlük'te, "kardiyo, hiper, tele ve ultra" kelimeleri yer almaz. Halbuki yukarıda örneklenen "kardiyo egzersizleri", "hiper güç", "ultra zengin" gibi kelime öbekleri bize açıç̧a göstermektedir ki bu kelimeler dilimize yerleşmiştir ve sözlüklerimizde yer almaları gerekir. (Anlamları yukarıda belirtilmiştir.) Bu noktada "tele" yapısı için bir parantez açılmalıdır. Dilimizde "tele" yapısının üç çeşit kullanımı vardır. Bunlardan birincisi dilimizde, kaynak dillerdeki şekilleriyle görülen "tele-“" ön ekli kelimelere örneklerdir (teleferik, telefon, telemetre...) ki bu yapılar dilimizde kök sayılmaktadır. Bir diğer kullanım ise isim görünümünde "televizyon" kelimesinin kısaltılmışı olarak kullanılan "tele" yapısıdır (Tele Pazar). Bu yapının Türkçe kurallarını adeta alt üst edişi Halil Ersoylu tarafından yetkin bir şekilde açıklanmıştır; “...bu çeşit kullanılışlarda Türk dilinin isim tamlamast yapısına uygun olarak tamlayan unsurunun belirli veya belirsiz ilgi (genitif) ekini almasl, tamlanan unsurunun ise grubun varliğ için şart olan iyelik ekini taşıması gerekmektedir... bu çeşit yapıların hepsinin isim tamlamast ile kurulabilirlik durumu yoktur." (Ersoylu, 1993: 330) "tele" yapısının üçüncü kullanılışı ise sıfat görünümündedir. (telekız, telekulak...) Fakat "tele" yapısı dilimizde tek başına bir anlam ifade etme yetisi kazanamamış olduğundan, dil kullanıcıları içgüdüsel olarak bu yapıları bitişik yazma yoluna gitmiş (TDK de, "telekız" kelimesini bu biçimiyle Güncel Türkçe Sözlük’te bulundurur.) ve bu durumda anlamsız bir yapıyla önce sıfat tamlaması ve ardından birleşik isim meydana getirilemeyeceğinden galat bir kullanım ortaya çıkmıştır. Ersoylu "tele-“" unsurunun Türk dilinde başlı başına bir kelime hüviyeti kazanmadığıyla ilgili şöyle söyler; "'tele- ' unsurunun Türk dilinde başlı başına bir kelime olmadı $\breve{g}$, bir ön ek niteliği taşımaya devam ettiğini gösteren delillerden biri de, onun, kendi başına, tek başına bir yerde kullanılamayışı; isim cinsinden kelimelerin, kelime grubu veya cümleye girebilmesini sağlayan çekim eklerinden herhangi birini alamaylşıdır." (Ersoylu, 1993: 331). Bu durumda Türkçenin batı kökenli ön ekleri kendi kurallarına uydurmak için almış olduğu önlemin henüz "tele-" yapısı için uygulanamamış olduğunu söyleyebiliriz. Dil canlı bir varlık olduğundan belki de bu yapıyı nihayetinde 
kendi kurallarına uyduracaktır. Fakat dilde istisna teşkil eden bu ve benzeri yapılar en azından bu biçimleriyle sondan eklemeli bir dil olan Türkçenin yapısına aykırı ve tehlikeli kullanımlardır. Bu kullanımların galat olduğunu fark etmek ve değerlendirmeleri buna göre yapmak gerekir.

b. TDK Büyük Türkçe Sözlük’te, “oto, kontra, kripto, daktilo, dinamo, ekstra, kilo, makro, maksi, mega, metro, mikro, midi, mini, foto, retro, süper, taksi, trans, video ve eks" kelimeleri yer alır. Fakat bu kelimelerden " mega, retro ve eks" yalnızca çeşitli terimler sözlüklerinin içindedir, terim anlamlarıyla tanımlanmıştır ve Güncel Türkçe Sözlük’e geçmemiştir. Üstelik Türkçede kelime olarak kullanılan "retro ve eks" için bu terim sözlükleri de "yabancı ön ek" tanımını yapmaktadır. Bu noktalara dikkat çekmek sözcük bilimi (leksikoloji) açısından önemlidir. Üzerinde durulması gereken bir başka nokta da genellikle terimler sözlüklerinde yer alan batı kaynaklı ön ek ve Türkçe menşeli kelimelerden oluşturularak bitişik yazılan yapılardır. Bir kelime öbeğinin kalıplaşarak birleşik sözcük oluşturabilmesi için dil içinde bir aşama geçirmiş olması gerekir. Halbuki söz konusu ön eklerin Türkçede kelime olarak kullanılması dil açısından nispeten yeni bir merhaledir. Bunların kelime olarak, ayrık yazımlı kullanımları tam anlamıyla yaygınlaşıp dile oturmadan yahut söz konusu ön ekler kelime görevlerini tam anlamıyla kazanamadan bitişik yazımların kullanımı, kişileri bu yapıların Türkçede ön ek göreviyle kullanıldığı yanlış yargısına götürebilir. Daha evvelden de söylenildiği gibi bu dil açısından oldukça tehlikelidir. Bu tür, yanlış olduğunu düşündüğümüz yapılara örnekler yukarıda "dilimizde, önündeki 'batı kaynaklı ön ek' yapısıyla bitişik yazılan Türkçe menşeli kelimelere örnekler" başlıkları altında sıralanmıştır.

- “Türkçede ön eklerin de var olduğu düşüncesini ortaya çıkaran kelimelerin öncelikle geldiği dildeki yapısını incelemek doğru bir tutum olacaktır.” (Şahin, 2006: 76) İnceleme yapıldığında bu kullanımların yapıları hakkında aşağıdaki gibi bir sinıflandırma ortaya çıkar;

a. Doğrudan batı kaynaklı ön eklerden dilimize geçerek dilimizde çoğunlukla sifat görevinde kullanılanlar: "kontra, eks/ex, hiper, mega, midi, tele (sıfat görünümünde olan)..." Bu yapıların Türkçede kelime olarak kullanılması dilimizin ön ekleri içine katarken aldığı bu önlem yöntemini açıkça bize göstermesi açısından önemlidir.

b. Kaynak dillerde ön ekli kelimelerden "kırpma/kısalama" (clipping/shortening) yöntemiyle kelime haline getirildikten sonra dilimize geçmiş olanlar: oto, kripto, daktilo, dinamo, ekstra, kilo, makro, maksi, metro, mikro, mini, foto, retro, süper, taksi, trans, video, kardiyo, ultra, tele (isim görünümünde olan)... $\mathrm{Bu}$ yapılar ise ön eklerle aynı yazımda/görünümde olmalarına rağmen dilimize geçmeden önce kendi dillerinde geçirdikleri merhaleler sonucu kelime görevi üstlenmiş örneklerdir. Bunlarla ilgili veriler, dilimizdeki söz konusu yapıların ön ek kullanımı olarak algılanmasının önüne geçecektir. 
- Dilimizde kaynak dillerdeki şekilleriyle görülen ön ekli kelimeler kök sayılır. Dolayısıyla bu da dilimizde ön ek kullanımı olduğunu göstermez. Bu tür yapılar makalede "Dilimizde, kaynak dillerdeki şekilleriyle görülen 'batı kaynaklı ön ek içeren' kelimelere örnekler" başlıkları altında sıralanmıştır.

- Türkçe, elbette ki yabancı kelimelerin istilasından korunmalıdır. Türkçe karşı1lıklar varken veya türetilebilecekken elbette ki yabancı kullanımlar tercih edilmemelidir. Fakat dil yaşayan bir varlıktır ve kullanıcılarının elinde doğal bir akış izler. Kullanıcılar tarafından ortaya koyulacak yapay önlemler işe yarayabileceği gibi dilin yabancı unsurlara karşı kendi önlemleri de vardır. Dilin bu doğal önlemleri, daha sağlam ve daha kalıcı sonuçlar doğurur. Dile girmekte olan yabancı unsurlara karşı dil bilincine sahip araştırmacılar endişe edip, önlemler almakta ve bu konuda uyarılarda bulunmakta son derece haklıdırlar. Ancak dikkatle bakıldığında gözlemlenebilecek olan dilin aynı yöntemleri kendi kendine uygulayabiliyor olma gücü de yok sayılmamalı ve dile bilhassa güçlü Türkçeye- olan güven ihmal edilmemelidir. İşte batı kaynaklı ön eklere de dilimizin yaptığı böyle doğal bir müdahaledir. Sondan eklemeli bir dil olan Türkçe yapısında bulunmayan ön ekleri içine katarken önlem almakta ve bu ön eklerin yapılarını değiştirerek onları kelime haline getirme yoluna gidebilmektedir.

- Dilimize girerek kullanıcıların hafızalarında yer edinmiş yabancı unsurları reddetmek yerine bunları tespit ederek sözlüklere almak sözcük bilimi (leksikoloji) açısından yararlı olacaktır. Dilin doğal akışını görmezden gelmek dile bir katkı sağlamaz ve endişeleri gidermek konusunda yardımcı olmaz. Eğer bir sorun varsa önce veriler toplanıp tespit edilmeli ve bu sorunların giderilmesi için neler yapılması gerektiği ondan sonra konuşulmalıdır. Aksi halde gerçekçi olmayan çözüm önerileri ortaya çıkacak ve yararlı bir sonuç elde edilemeyecektir.

- Sözün özü, Türkçe sondan eklemeli bir dildir. Yapısında ön ek bulundurmaz. Türk dilinin doğal önlem yöntemleriyle batı kaynaklı ön ekleri kendi yapısına uydurarak kelime şeklinde kullanması bu gerçeğe açık bir kanıttır.

\section{REFERENCES}

- AYDOĞAN, B. (2006). Ex Așkım, Eks Aşkın, Ex Aşkı, Türk Dili Dergisi, sy. 660, s.507-516.

- ERSOYlU, H. (1993). Batı Kökenli Ön Ek'lerin Türk Dilinde Kelime Olarak Kullanılması, Türk Dili Dergisi, sy. 497, s. 326-334.

- NişANYAN, S. (2012). Sözlerin Soyağacı, Everest Yayınları, İstanbul.

- ŞAHIN, H. (2006). Türkçe'de Ön Ek, U.Ü. Fen-Edebiyat Fakültesi Sosyal Bilimler Dergisi, Y11:7 sy. 10, s.65-77.

- TDK (2011). Türkçe Sözlük, Ankara: Türk Dil Kurumu Yayınları.

- ÜSTÜNOVA, K. (2010). Dil Bilgisi Sorunları, Kesit Yayınları, İstanbul.

\section{INTERNET REFERENCES}

- http://arsiv.sabah.com.tr/2007/05/05/ct/haber,5768DBAB4271497A8E08A4E3F06440 71.html, 08.06.2015. 
- http://arsiv.sabah.com.tr/2007/11/16/haber,64C75BBB8B9D4143BB31E874FFCBCB 98.html, 08.06.2015.

- http:// dictionary.reference.com, 08.06.2015.

- http://www.aksam.com.tr/teknoloji/islemci-ve-ramde-yeni-donem-basliyor-30009h/haber-30009, 08.06.2015.

- http://www.cnnturk.com/2013/guncel/05/04/yasar.kemalin.ince.memedi.korsan.filmcil erin.elinde.nasil.ince.mehmet.oldu/706605.0, 08.06.2015.

- http://www.cumhuriyet.com.tr/haber/diger/238028/Turk_ogrenciler_Paris_te_toplandi .html , 08.06.2015.

- http://www.cumhuriyet.com.tr/haber/saglik/57323/Duzenli_egzersiz_beyni_guclendi riyor_html, 08.06.2015.

- http://www.cumhuriyet.com.tr/haber/turkiye/140057/istanbul_da_taksiler_icin_yeni_d onem_Taksiciler_tepkili.html, 08.06.2015.

- http://www.cumhuriyet.com.tr/haber/turkiye/232779/Kripto_sorusturmasinda_agirlasti rilmis_muebbet_istemi.html, 08.06.2015.

- http://www.cumhuriyet.com.tr/koseyazisi/241988/isletme_Yonetimlerine_Odaklanma k....html , 08.06.2015.

- http://www.gazetevatan.com/10-kucuk-degisiklikle-5-kilo-verin--747615-pazar-vatan, 08.06.2015.

- http://www.gazetevatan.com/feriha-hamile-mi--457096-medya , 08.06.2015.

- http://www.gazetevatan.com/is-adamindan-telekiz-servisi--599450-gundem 08.06.2015.

- http://www.gazetevatan.com/tem-otoyolunda-bir-garip-olay--785082yasam, 08.06.2015.

- http://www.haberturk.com/yasam/haber/1023969-2015-e-sicacik-merhaba 08.06.2015.

- http://www.hurriyet.com.tr/ankara/28763748.asp, 08.06.2015.

- http://www.hurriyet.com.tr/gundem/27765827.asp , 08.06.2015.

- http://www.hurriyet.com.tr/index/ArsivNews.aspx?id=3942982, 08.06.2015.

- http://www.hurriyet.com.tr/spor/futbol/26469145.asp , 08.06.2015.

- http://www.hurriyet.com.tr/spor/futbol/26835644.asp, 08.06.2015.

- http://www.hurriyet.com.tr/spor/futbol/27761364.asp , 08.06.2015.

- http://www.milliyet.com.tr/2006/02/13/dunya/axdun02.html , 08.06.2015.

- http://www.milliyet.com.tr/hayvan-daminda-elektrik-uretti-ozel-balikesir-yerelhaber$602357,08.06 .2015$.

- http://www.milliyet.com.tr/-ret-ro---wil-ma-magazin-1959165, 08.06.2015.

- http://www.milliyet.com.tr/trans-oldurmek-indirime-gerekce--gundem-1892227, , 08.06.2015.

- http://www.milliyet.com.tr/ultra-zenginlerin-sayisi artti/ekonomi/detay/1972312/default.htm , 08.06.2015.

- http://www.radikal.com.tr/dunya/abd_artik_super_guc_olmayacak-1058816 08.06.2015.

- http://www.radikal.com.tr/turkiye/milliyet_muhabiri_suriyede_kacirildi-1166697, 08.06.2015.

- http://www.sabah.com.tr/cumartesi/2011/04/30/ilkbahar--yaz-trendleri , 08.06.2015.

- http://www.sabah.com.tr/dunya/2013/02/17/mini-etekle-meclise-gelinir-mi 08.06.2015.

- http://www.sabah.com.tr/gundem/2015/02/27/mega-proje-aciklandi , 08.06.2015. 
- http://www.sabah.com.tr/yazarlar/uluc/2008/04/05/yillar_sonra_tele-pazar_a_donus, 08.06.2015.

- http://www.tdk.gov.tr/index.php?option=com_bts\&view=bts , 08.06.2015.

- http://www.tdk.gov.tr/index.php?option=com_gts\&view=gts , 08.06.2015.

- http://www.tdk.gov.tr/index.php?option=com_gts\&arama=gts\&guid=TDK.GTS.5575 87933f1270.52136440, 08.06.2015.

- http://www.turkiyegazetesi.com.tr/yildiray-ogur/577933.aspx , 08.06.2015. 